\title{
Morphometric Analysis of Corpus Callosum with Magnetic Resonance Imaging in Children; Correlation with Age and Gender
}

\section{Hatice Arıöz Habibi $\odot$ Ozan Berk Gül $\odot$ Emine Caliskan $\odot$ Mehmet Öztürk $\odot$}

\author{
Çocuklarda Korpus Kallozumun Manyetik Rezonans \\ Görüntüleme ile Morfometrik Analizi; Yaş ve \\ Cinsiyetle Korelasyon
}

ABSTRACT

Objective: Corpus Callosum (CC) is a dynamic organ that undergoes morphological modifications throughout life which must be taken into account for appropriate evaluation of CC. The objectives of this study were to provide normative data about the morphological modifications in CC during childhood and to evaluate possible differences related to age and sex.

Methods: In this retrospective study, cranial MRI studies of 320 children (160 boys, and 160 girls) between 2 to 17 years old with normal neurologic examination findings were reviewed. We divided the age groups as increments of 1 year, and included 10 girls and 10 boys, in each age group. The following parameters were measured on midsagittal T1-weighted images: area of CC (CCA), supracallosal area (SCA), length of CC (LCC), genu thickness (GT), body thickness (BT), splenium thickness (ST), ratio of genu thickness to splenium thickness (GT/ST) and a novel parameter termed callosal index (CCA/SCA). These parameters were correlated with age and sex.

Results: All parameter values increased with age. After age 10, there was no evident age or genderrelated changes between groups, except for the 15-year-old group. When we appraised all age groups, we determined that CCA and SCA were larger in boys but the callosal index did not differ between genders. Conclusion: This is the first study which used the modified callosal index in the pediatric age group. Callosal index gives the opportunity to make brain size corrections according to the individual and allows a more accurate and personal measurement in the follow-up of the same individual. This study offers an objective assessment measure.

Keywords: Corpus callosum, magnetic resonance imaging, biometry, callosal index, pediatrics

öz

Amaç: Korpus Kallozum (KK), yaşam boyu morfolojik değişiklikler gösteren dinamik bir organdır. Günlük pratikte KK değerlendirmesi subjektif yapılsa da daha doğru değerlendirme yapabilmek yaş ve cinsiyete göre hazırlanmış referans değerlere ihtiyaç vardır. Bu çalışmanın amacı, çocuklarda yaş grubuna göre referans değerleri sağlamanın yanı sıra ve yas ve cinsiyet farkıııklarını değerlendirmektir. Ek olarak kișinin kendi KK'si ile beyin alanını oranlayarak kişiselleştirilmiş ölçüm yapılmasına imkan veren Modifiye Kallozal indeksi çocuklarda değerlendirmeyi amaçladık.

Yöntem: Retrospektif dizayn edilmiş çalışmamızda, nörolojik muayene bulguları normal olan 2-17 yaş arası 320 çocuğun (160 erkek, 160 kIz) kraniyal MRG'leri incelendi. Midsagittal planda T1 görüntülerde: KK alanı (CCA), suprakallozal alan (SCA), KK uzunluğu (LCC), genu kalınlığı (GT), gövde kalınlığı (BT), splenium kalınlığı (ST), genu kalınlığının splenium kalınlığına oranı (GT / ST) ve callosal indeksi (CCA / SCA) olarak adlandırılan yeni bir parametre değerlendirildi. Bu parametrelerin yaş ve cinsiyet ile ilişkisi değerlendirildi.

Bulgular: Değerlendirilen tüm parametreler yaşla artış göstermiştir. 10 yaşından sonra 15 yaşındaki grup dışında, gruplar arasında yaş veya cinsiyetle ilgili istatistiksel olarak anlamlı farklılık saptanmadı. Tüm yaş gruplarını değerlendirdiğimizde, erkek çocuklarda CCA ve SCA'nın daha büyük olduğunu ancak kallozal indeksin cinsiyetler arasında istatistiksel olarak anlamlı farklılık göstermediğini belirledik.

Sonuç: Çalışmamız, KK değerlendirilirken yaşa ve cinsiyete göre gösterdiği değişikliği göz önünde bulundurarak objektif ölçüme olanak sağlayan bir referans değer belirlemesi açısından önemlidir. Ayrıca kantitatif modifiye kallozal indeksi çocuklarda kullanan ilk çalışmadır.

Anahtar kelimeler: Korpus kallozum, Manyetik rezonans görüntüleme, biyometri, kallozal indeks, pediatri
Received: 23.01.2021

Accepted: 06.05.2021

First Publication: 20.09.2021

Cite as: Arı̈z Habibi H, Gül OB, Caliskan E, Öztürk M. Morphometric analysis of corpus callosum with magnetic resonance imaging in children; correlation with age and gender. Izmir Dr. Behçet Uz Çocuk Hast. Dergisi. 2021;11(3):277-85.

Hatice Arıöz Habibi

Özel Varisson Radyoloji Merkezi,

Radyoloji Bölümü,

Antalya, Türkiye

arioz.hatice@gmail.com ORCID: 0000-0002-4113-596X

O.B. Gül 0000-0001-8321-2276 M. Öztürk 0000-0001-5585-1476 Selçuk Üniversitesi Tıp Fakültesi, Radyoloji Anabilim Dalı, Konya, Türkiye

E. Çalışkan 0000-0001-9869-1396 Sağlık Bilimleri Üniversitesi Kartal Lüfi Kırdar Eğitim ve Araştırma Hastanesi, Radyoloji Bölümü, istanbul, Türkiye 


\section{INTRODUCTION}

The corpus callosum (CC) is the most significant forebrain commissure, a true evolutionary modification only seen in placental mammals ${ }^{(1,2)}$. The first role of CC is to assemble and transfer data between the two hemispheres. The $\mathrm{CC}$ processes sensory, motor, and high-level cognitive signals (3). The posterior part of the CC transfers visual, auditory, and somatosensory information. Higher cognitive functions are processed in the anterior part of the $\mathrm{CC}^{(3)}$. As the brain structures evolve, the CC improves motor movements and develops cognitive functions ${ }^{(3,4)}$. Fiber composition of the CC changes with differing proportions of small and large diameter fibers across callosal subregions. The splenium and genu have high density of short fibers; however, the corpus contains large diameter fibers. Morphological differences and morphological changes in the CC throughout infancy lead to assessment and measurement challenges for each segment and size ${ }^{(5)}$.

A large number of studies have demonstrated that the callosal abnormalities are related with neurological disorders, learning disabilities, aphasia, schizophrenia, dyslexia and spastic cerebral palsy (6-10). Because of these adverse conditions, and in consideration of changes associated with age and gender, it is very important to distinguish the appearance of normal CC from the pathological one, and only visual evaluation is not sufficient to make this distinction.

Several different imaging modalities can be used in the assessment of CC. Ultrasound is an advantageous method, in that it is an easily available, cost-effective, radiation-free bedside procedure which provides real-time information. Unfortunately, ultrasound can only be used for CC screening in the prenatal and only in the early postnatal period until the anterior fontanel closes. Although computed tomography (CT) appears to be advantageous over magnetic resonance imaging (MRI) with shorter procedural time, it is not recommended for the evaluation of CC due to the high radiation exposure and low soft tissue resolution relative to MRI. MR images in the midsagittal plane are useful for measurement of CC length and evaluating subsegmental anatomy. However, in many reference centers, CC is assessed visually without measuring the dimensions of CC. Failure to obtain standard measurement data for fellows or residents who have just started pediatric neuroradiology practice may lead to difficulties in structured reporting. To date, there are limited number of studies in the literature about biometric evaluation of the size and thickness of CC in children ${ }^{(5,6,11,12)}$. There is a need for standard normative biometric data about the $\mathrm{CC}$ that are easy to use in daily practice.

The aims of this study were to provide reference biometric data about the CC with MR imaging in children and to evaluate possible impact of age and gender on biometric and morphologic characteristics of CC. Normal values may be used to differentiate and evaluate developmental diseases or diseases that may lead to changes in CC structure in the future.

\section{MATERIAL and METHODS}

\section{Patient Selection}

Cranial MR imaging data were selected from the hospital Picture Archiving Communication Systems (PACS) encompassing the period extending from March 2018 to January 2020. Local ethics committee approval was obtained prior to initiation of the study (02.19.2020/file number: 2020/77). We assessed a total of 320 cases including 160 males and 160 females, with ages ranging from 2-17 years (median age: 9.5 years). The MR imaging studies were performed for a variety of symptoms like seizures, myoclonus, dizziness, balance disorders, precocious puberty, headache, abnormal visual findings, deafness, facial palsy. Patients without cerebral pathology identified on MRI were included the study.

Children with metabolic disorders, cranial trauma, intracranial hemorrhage, intracranial mass, cerebral edema, hydrocephalus, cranial malformation, cerebral atrophy and multiple extracerebral malformations, any pathologic cranial findings, 
premature birth and suboptimal image quality were excluded from the study.

Cases were stratified by age in increments of 1 year and each age group was evaluated separately. Each group contained 10 male and 10 female cases with a total of 20 individuals in every age group. Evaluation of MR images was performed by a pediatric radiologist with more than 8 years of experience in pediatric neuroradiology.

\section{MR imaging and measurements}

MR imaging was performed on a $1.5 \mathrm{~T}$ scanner (Magnetom Aera; Siemens AG Healthcare Sector,

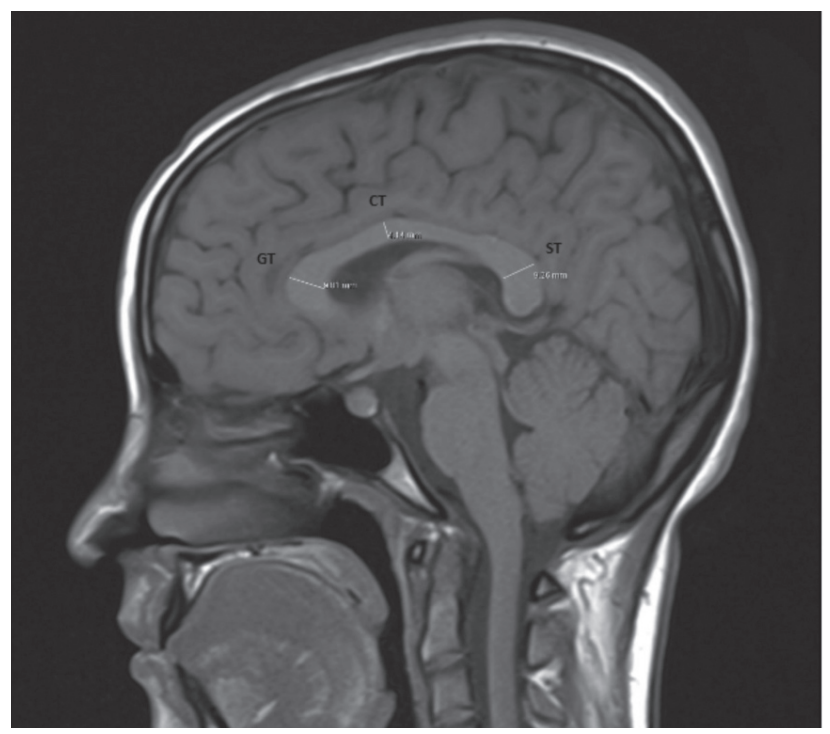

Figure 1. Measurement of the thickness of the CC, at the level of the genu (GT), corpus (CT), and splenium (ST).

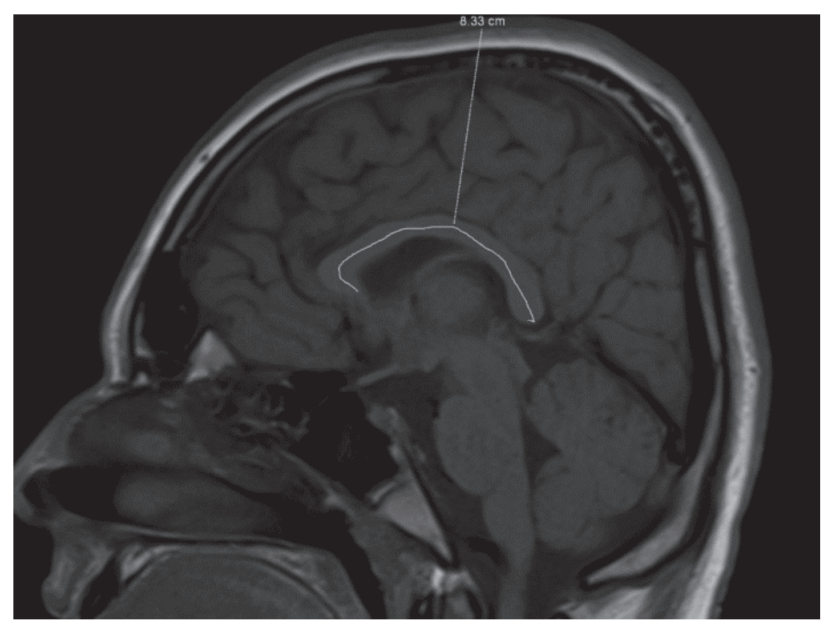

Figure 2. Measurement.
Erlangen, Germany) and midsagittal T1-weighted images which best illustrated the CC were selected for evaluation. Parameters for T1-weighted images were as follows: FOV: $230 \mathrm{~mm}$, matrix: 256x256, slice thickness: $5 \mathrm{~mm}$, interslice gap: $1 \mathrm{~mm}$, NEX: 2, and TR/TE: 562/14 msec. We have chosen T1 sequence, because it allows the best morphologic evaluation.

On midsagittal T1-WI, thickness of CC was measured at the level of genu, body and splenium
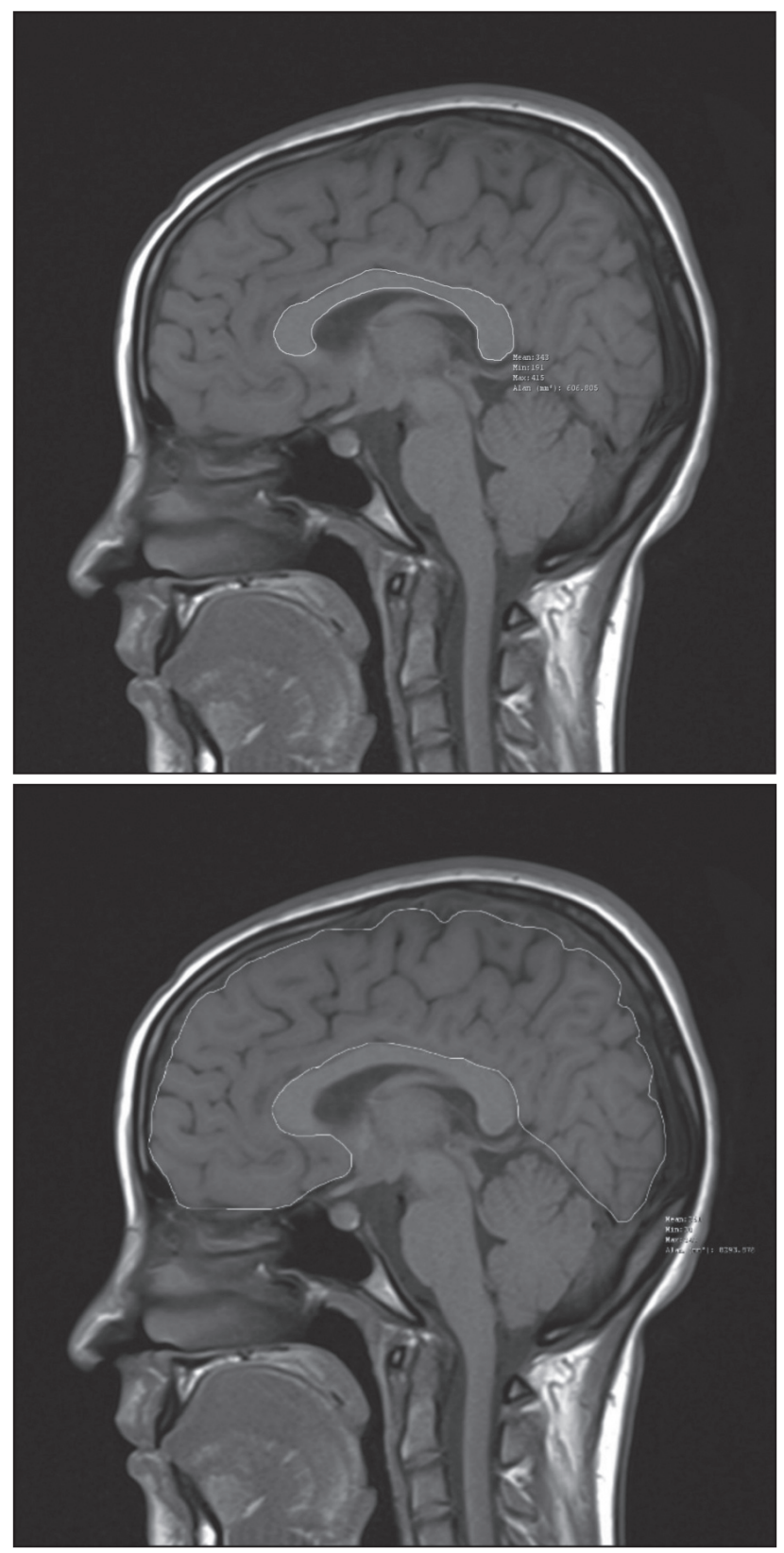

Figure 3-4. Sagittal T1-weighted MR image demonstrates the area measurements for index calculation. Area of CC (Figure 3) and area of supracallosal cerebral parenchymal area (Figure 4). 
Table 1. Biometric parameters evaluated in the study.

\begin{tabular}{lll}
\hline Abbreviation & Parameter & Definition \\
\hline LCC & True length of CC & Curvilinear distance between the rostrum and the splenium at mid-thickness of the \\
GT & Genu Thickness of the CC & CC \\
BT & Body Thickness of the CC & Thickness of the CC measured at the level of the genu \\
ST & Splenium Thickness of the CC & Thickness of the CC measured at the level of the body \\
CCA & Area of CC $\left(\mathrm{mm}^{2}\right)$ & Thickness of the CC measured at the level of the splenium \\
SCA & Supracallosal area $\left(\mathrm{mm}^{2}\right)$ & The area inside of a closed line crossing the CC \\
GT/ST & Genu-splenium thickness ratio & The area of supracallosal brain parenchyma \\
CCA/ SCA & Callosal Index & Ratio of genu thickness to splenium thickness \\
& & Ratio of callosal area to supracallosal area \\
\hline
\end{tabular}

CC: Corpus Callosum, LCC: True length of CC, GT: genu thickness, BT: body thickness, ST: splenium thickness, GT / ST: the ratio of genu thickness to splenium thickness, CCA: area of corpus callosum, SCA: supracallosal area, Callosal index: Ratio of callosal area to supracallosal area

(Figure 1). True length of CC was measured as the curvilinear distance between the rostrum and the splenium at midthickness of the CC (Figure 2). Ratio of GT to ST was calculated.

A region of interest was placed around the $\mathrm{CC}$ and area of CC at midsagittal plane was measured (Figure 3). Subsequently, the supracallosal area at the same level was measured by placing a region of interest on it (Figure 4). Area measurements were calculated automatically by the device. Callosal index indicating ratio of CC area to supracallosal area was calculated. Analysis of morphological parameters is detailed in Table 1.

\section{Statistical analysis}

Kolmogorov-Smirnov test was used to examine whether the quantitative variables had a normal distribution. For independent groups, variables with normal distribution were compared with t test oneway analysis of variance (ANOVA), and variables that were not normally distributed were compared with Mann-Whitney $\mathrm{U}$ test or Kruskal-Wallis $\mathrm{H}$ test. The relationship between quantitative variables and age was examined with the Spearman correlation analysis. Descriptive statistics of variables with normal distribution are presented as mean \pm standard deviation, and descriptive statistics of non-normally distributed quantitative variables are shown as median $\left(25^{\text {th }}-75^{\text {th }}\right.$ percentile). Descriptive statistics for qualitative variables are expressed as frequency (\%). $p<0.05$ values were considered statistically significant. Accordingly, descriptive statistics for BT and GT/ST variables are shown as median (25-75 percentile) and descriptive statistics for $\mathrm{GT}, \mathrm{BT}, \mathrm{ST}$, CCA, SCA, LCC, CCA/SCA and GT/ST variables are stated as arithmetic mean \pm standard deviation. Accordingly, descriptive statistics for SCA and CCA/ SCA variables are given as arithmetic mean \pm standard deviation.

\section{RESULTS}

Descriptive statistics for quantitative variables are given in Table 2. In the 2, 3, 7 and 15 year-age groups, SCA was larger in boys than in girls, GT in the 4 year-age group and GT/ST ratio in the 5 year-age group was higher in girls, and the GT/ST ratio was greater in boys in the 12-year age group. Under the normality assumption, descriptive statistics for quantitative variables of 320 individuals are given in Table 2. Descriptive statistics for quantitative

Table 2. Descriptive statistics of quantitative variables.

\begin{tabular}{lc}
\hline GT $(\mathrm{mm})$ & $8.25 \pm 1.50$ \\
BT $(\mathrm{mm})$ & $4.10(3.59-4.74)$ \\
ST $(\mathrm{mm})$ & $8.08 \pm 1.49$ \\
CCA $\left(\mathrm{mm}^{2}\right)$ & $521.65 \pm 95.90$ \\
SCA $\left(\mathrm{mm}^{2}\right)$ & $8029.24 \pm 891.47$ \\
LCC $(\mathrm{mm})$ & $79.85 \pm 7.48$ \\
CCA $/ \mathrm{SCA}$ & $0.07 \pm 0.01$ \\
GT/ST & $1.02(0.89-1.14)$
\end{tabular}

CC: Corpus Callosum, LCC: True length of CC, GT: genu thickness, BT: body thickness, ST: splenium thickness, GT / ST: the ratio of genu thickness to splenium thickness, CCA: area of corpus callosum, SCA: supracallosal area, Callosal index: Ratio of callosal area to supracallosal area. 
Table 3. Descriptive statistics of quantitative variables in gender groups.

\begin{tabular}{lccc}
\hline & \multicolumn{2}{c}{ GENDER } \\
\cline { 2 - 3 } VARIABLES & Girls $(\mathbf{n = 1 6 0})$ & Boys $(\mathbf{n}=\mathbf{1 6 0})$ & P \\
& & & \\
GT $(\mathrm{mm})$ & $8.24 \pm 1.43$ & $8.26 \pm 1.57$ & 0.905 \\
BT $(\mathrm{mm})$ & $4.06(3.59-4.72)$ & $4.25(3.59-4.80)$ & 0.346 \\
ST $(\mathrm{mm})$ & $8.06 \pm 1.48$ & $8.10 \pm 1.50$ & 0.849 \\
CCA $\left(\mathrm{mm}^{2}\right)$ & $508.74 \pm 91.21$ & $534.56 \pm 98.99$ & 0.016 \\
SCA $\left(\mathrm{mm}^{2}\right)$ & $7782.83 \pm 849.91$ & $8275.66 \pm 865.96$ & $0.001>$ \\
LCC $(\mathrm{mm})$ & $79.10 \pm 6.89$ & $80.61 \pm 7.99$ & 0.072 \\
CCA/SA & $0.07 \pm 0.01$ & $0.06 \pm 0.01$ & 0.443 \\
GT/ST & $1.03(0.89-1.14)$ & $1.02(0.89-1.14)$ & 0.762 \\
& & & \\
\hline
\end{tabular}

CC: Corpus Callosum, LCC: True length of CC, GT: genu thickness, BT: body thickness, ST: splenium thickness, GT / ST: the ratio of genu thickness to splenium thickness, CCA: area of corpus callosum, SCA: supracallosal area, Callosal index: Ratio of callosal area to supracallosal area. variables according to gender are given in Table 3 . Accordingly, descriptive statistics for BT and GT/ST variables are shown as median (25-75 percentile), descriptive statistics for GT, ST, CCA, SCA, LCC and CCA/SCA (callosal index) variables are stated as arithmetic mean \pm standard deviation. According to the results of the correlation analysis, SCA and CCA values were significantly higher in boys than girls. But the callosal index was identical for girls and boys. Descriptive statistics for quantitative variables by age groups are given in Table 4.

In our study, we found a moderate positive correlation between age and CCL, GT, ST, CCA, and SCA. A weak positive correlation was present between age, BT and CCA/SCA. Results of correlation analysis for quantitative variables with age is given in Table 5. All parameters increased with age.

Table 4. Descriptive statistics of quantitative variables in age groups.

\begin{tabular}{|c|c|c|c|c|c|c|c|c|}
\hline \multirow[b]{2}{*}{ Variables } & \multicolumn{8}{|c|}{ AGE GROUPS } \\
\hline & $\begin{array}{c}2 \\
(n=20)\end{array}$ & $\begin{array}{c}3 \\
(n=20)\end{array}$ & $\begin{array}{c}4 \\
(n=20)\end{array}$ & $\begin{array}{c}5 \\
(n=20)\end{array}$ & $\begin{array}{c}6 \\
(n=20)\end{array}$ & $\begin{array}{c}7 \\
(n=20)\end{array}$ & $\begin{array}{c}8 \\
(n=20)\end{array}$ & $\begin{array}{c}9 \\
(n=20)\end{array}$ \\
\hline $\mathrm{GT}(\mathrm{mm})$ & $6.23(5.43-7.15)$ & $7.23(6.37-7.75)$ & $6.75(5.91-7.61)$ & $7.40(6.73-8.81)$ & $7.57(6.41-8.52)$ & $8.76(7.63-9.52)$ & $8.68(8.07-9.71)$ & $8.73(8.06-9.84)$ \\
\hline BT (mm) & $3.28(3.13-3.76)$ & $4.20(3.52-4.51)$ & $3.75(3.24-4.46)$ & $3.85(3.62-4.96)$ & $4.04(3.59-4.51)$ & $4.39(3.59-4.67)$ & $4.39(4.04-4.74)$ & $4.04(3.55-4.51)$ \\
\hline ST (mm) & $6.27(5.86-6.92)$ & $7.23(6.10-8)$ & $6.89(6.18-7.43)$ & $6.89(6.30-7.68)$ & $8(6.63-8.37)$ & $7.77(6.53-8.50)$ & 8.17 (7.57-9.29) & $8.09(7.29-9.03)$ \\
\hline $\mathrm{CCA}(\mathrm{mm})$ & $\begin{array}{c}352.45 \\
(329.15-429.78)\end{array}$ & $\begin{array}{c}454.55 \\
(397.13-489.80)\end{array}$ & $\begin{array}{c}423.95 \\
(400.50-475.40)\end{array}$ & $\begin{array}{c}480.10 \\
(437.03-566.40)\end{array}$ & $\begin{array}{c}462.10 \\
(428.85-558.85)\end{array}$ & $\begin{array}{c}520.50 \\
(479.55-583.13)\end{array}$ & $\begin{array}{c}552.80 \\
(504.33-576.10)\end{array}$ & $\begin{array}{c}496.10 \\
(460.43-588.30)\end{array}$ \\
\hline $\mathrm{SCA}\left(\mathrm{mm}^{2}\right)$ & $6460.58 \pm 774.06$ & $7393.70 \pm 649.76$ & $7329.70 \pm 851.82$ & $7708.68 \pm 528.60$ & $7873.07 \pm 953.39$ & $8226.74 \pm 796.95$ & $8081.92 \pm 670.85$ & $8098.13 \pm 719.07$ \\
\hline $\operatorname{LCC}(\mathrm{mm})$ & 71 (66.75-73) & 75 (70.50-76.75) & $80(70-82)$ & $78(73-82)$ & $74(71.25-81.75)$ & $78(71.25-86.50)$ & $80.50(77-85)$ & $78.50(76-82)$ \\
\hline CCA/SA & $0.059 \pm 0.011$ & $0.061 \pm 0.009$ & $0.059 \pm 0.007$ & $0.064 \pm 0.011$ & $0.064 \pm 0.010$ & $0.065 \pm 0.011$ & $0.068 \pm 0.008$ & $0.064 \pm 0.010$ \\
\hline $\mathrm{GT} / \mathrm{ST}$ & $0.98(0.86-1.12)$ & $0.97(0.87-1.13)$ & 1 (0.91-1.15) & $1.08(0.98-1.21)$ & $0.96(0.89-1.11)$ & $1.16(0.94-1.40)$ & $1.06(0.97-1.14)$ & $1.07(0.92-1.24)$ \\
\hline
\end{tabular}

Table 4. continued .

\begin{tabular}{|c|c|c|c|c|c|c|c|c|}
\hline \multirow[b]{2}{*}{ Variables } & \multicolumn{8}{|c|}{ AGE GROUPS } \\
\hline & $\begin{array}{c}10 \\
(n=20)\end{array}$ & $\begin{array}{c}11 \\
(n=20)\end{array}$ & $\begin{array}{c}12 \\
(n=20)\end{array}$ & $\begin{array}{c}13 \\
(n=20)\end{array}$ & $\begin{array}{c}14 \\
(n=20)\end{array}$ & $\begin{array}{c}15 \\
(n=20)\end{array}$ & $\begin{array}{c}16 \\
(n=20)\end{array}$ & $\begin{array}{c}17 \\
(n=20)\end{array}$ \\
\hline $\mathrm{GT}(\mathrm{mm})$ & 8.68 (7.96-9.91) & 8.65 (7.47-9.42) & $8.59(7.28-9.42)$ & 8.56 (7.75-9.16) & $9.44(7.90-10.02)$ & $8.41(7.51-9.11)$ & $9.13(8.27-9.91)$ & $9.28(8.64-10.16)$ \\
\hline $\mathrm{BT}(\mathrm{mm})$ & $4.30(3.64-5.28)$ & $4.01(3.59-4.51)$ & 3.96 (3.59-4.77) & $4.06(3.93-5.16)$ & $4.21(3.64-5.28)$ & $4.50(3.70-4.96)$ & $4.63(4.08-5.16)$ & $4.93(3.74-5.39)$ \\
\hline $\mathrm{ST}(\mathrm{mm})$ & $7.66(7.38-8.54)$ & $8.32(7.43-8.72)$ & $8.26(7.40-9.55)$ & $8.46(7.43-10.40)$ & $8.88(8.27-9.94)$ & 9.49 (8.56-10.49) & $9.11(8.35-9.68)$ & 9.06 (8.14-10.09) \\
\hline $\mathrm{CCA}(\mathrm{mm})$ & $\begin{array}{c}539.45 \\
(466.28-624.10)\end{array}$ & $\begin{array}{c}528.05 \\
(490.13-573.45)\end{array}$ & $\begin{array}{c}512.55 \\
(463.35-592.55)\end{array}$ & $\begin{array}{c}568.78 \\
(523.63-643.78)\end{array}$ & $\begin{array}{c}558.40 \\
(514.50-607.95)\end{array}$ & $\begin{array}{c}584.65 \\
(496.90-647.50)\end{array}$ & $\begin{array}{c}576.90 \\
(527.13-598.10)\end{array}$ & $\begin{array}{c}593.26 \\
(531.83-652.63)\end{array}$ \\
\hline $\mathrm{SCA}(\mathrm{mm} 2)$ & $8533.51 \pm 782.69$ & $8404.92 \pm 575.02$ & $8349.02 \pm 657.68$ & $8408.04 \pm 750.42$ & $8410.13 \pm 770.59$ & $8415.43 \pm 744.49$ & $8310.82 \pm 582.91$ & $8463.52 \pm 631.40$ \\
\hline $\operatorname{LCC}(\mathrm{mm})$ & $79.50(74-84.25)$ & 83 (79-88) & $82(77.25-86.75)$ & $82.50(79.25-87)$ & $83.50(78-87)$ & $84.50(77.75-87)$ & $82.50(80-84)$ & $85.50(81-87)$ \\
\hline CCA/SA & $0.064 \pm 0.008$ & $0.065 \pm 0.008$ & $0.063 \pm 0.011$ & $0.069 \pm 0.009$ & $0.068 \pm 0.011$ & $0.068 \pm 0.010$ & $0.069 \pm 0.009$ & $0.070 \pm 0.010$ \\
\hline $\mathrm{GT} / \mathrm{ST}$ & $1.11(1.01-1.28)$ & $1.06(0.91-1.17)$ & $0.94(0.88-1.13)$ & $0.94(0.81-1.17)$ & $1.02(0.82-1.14)$ & $0.94(0.80-1.02)$ & $1.04(0.93-1.12)$ & $1.05(0.87-1.13)$ \\
\hline
\end{tabular}

CC: Corpus Callosum, LCC: True length of CC, GT: genu thickness, BT: body thickness, ST: splenium thickness, GT / ST: the ratio of genu thickness to splenium thickness, CCA: area of corpus callosum, SCA: supracallosal area, Callosal index: Ratio of callosal area to supracallosal area. 
Table 5. Results of correlation analysis of quantitative variables with age.

\begin{tabular}{ccccccccc}
\hline & GT & BT & ST & CCA & SCA & LCC & CCA/SA & GT/ST \\
\hline Age & $r=0.498$ & $r=0.269$ & $r=0.596$ & $r=0.541$ & $r=0.491$ & $r=0.466$ & $r=0.288$ & $r=-0.059$ \\
& $p<0.001$ & $p<0.001$ & $p<0.001$ & $p<0.001$ & $p<0.001$ & $p<0.001$ & $p<0.001 \quad r=0.294$ \\
\hline
\end{tabular}

$r$ : Correlation coefficient

CC: Corpus Callosum, LCC: True length of CC, GT: genu thickness, BT: body thickness, ST: splenium thickness, GT / ST: the ratio of genu thickness to splenium thickness, CCA: area of corpus callosum, SCA: supracallosal area, Callosal index: Ratio of callosal area to supracallosal area.

\section{DISCUSSION}

To our knowledge this is the largest MR imaging study to investigate the efficiency of age and gender on multiple measurements of CC morphology and its subsegments in healthy children, and the first study which used modified callosal index in pediatrics.

The corpus callosum is the most important commissure in the human brain, connecting cortical regions of both hemispheres. The $\mathrm{CC}$ is the largest commissure, existing of more than 200-300 million fibers of various lengths, connecting both hemispheres. Myelination of this commissure, which is present from birth, continues throughout puberty (13). Although there is no anatomically obvious border in the CC, it is topographically divided into 5 sections from anterior to posterior as rostrum, genu, body, isthmus, and splenium. Callosal length and width displayed significant differences based on sex and age of the individuals ${ }^{(13-16)}$. Variations among studies may be caused by being without brain size corrections, differences in patient groups or devices and the method of measurement. In this study we added a new parameter of callosal index to evaluate the CC more objectively, accounting for variations in cerebral size.

\section{Callosal Index}

Callosal index is estimated by proportioning CC area with the supracallosal area. Callosal index gives the opportunity to make individualized brain size corrections and allows more accurate and personal measurement in the follow-up of the same individual.

Erdogan et al. ${ }^{(17)}$ evaluated callosal index in adults and found no significant difference between genders. Erdoğan et al. used midsagittal T1-weighted images.
First, they calculated the area inside of a closed line crossing the CC. Later, supratentorial areas were calculated and proportioned by them. Like their study, we also found that callosal index did not show differences between girls and boys in all pediatric age groups. In the literature, there are very old two studies in which callosal index was used in children ${ }^{(11,18)}$. But they are different from our study due to the measurement technique and developments in MR technology.

The measurement technique of Rauch and Jinkins is different from ours. They proportioned the CC area to the average of the cerebral areas calculated in the axial and sagittal planes ${ }^{(11)}$. In line with the study of Rauch and Jinkins, we observed that the supracallosal area grows with age and the callosal index does not differ between genders.

Schaefer et al. ${ }^{(18)}$ measured the total cerebral parenchyma by dividing it into 4 different parts using MR images and photo printing technique. It is quite different from ourstudy in terms of both measurement technique and possible errors that may arise from using different measurement tools.

Since dura mater is a good reference line for distinction of the supratentorial area, in our study we used ST for the calculation of the ratio. The method we used to estimate callosal index is different from previously used ones, and seems to be a method with high ease of application and reproducibility. It is also a parameter that can be used confidently in follow-up of the same cases by minimizing variations among individuals.

\section{CCA and SCA}

In our study consistent with Erdogan et al. ${ }^{(17)}$ the supratentorial area and CC area of boys were found 
to be significantly larger than girls. Clarke et al. ${ }^{(19)}$ performed brain examination in the postmortem period on children aged 28 weeks to 14 years. They found that CCA was larger in boys than girls, as in our study. Clarke et al. stated that the difference in CC size may have been solely related to the differences in brain size.

In support of this, the disparity reported between boys and girls in terms of CC size was about 15 percent.

\section{The length of $\mathrm{CC}$}

To the best of our knowledge, very few studies in the literature evaluated true curvilinear length of CC (3). In our study, we preferred to examine, and use curvilinear measurement technique, even though it was more demanding and meticulous. We did not find a significant difference in LCC measurements among age and sex groups, except the 15-year-old group, which could be called preadults. In this age group LCC in boys was significantly longer than girls. Also, we found that supracallosal area was larger in boys than girls in the 15 -year-old group. The difference between sexes in this age group in LCC may be the result of the diffuse growth of CC due to hormonal changes. As shown in functional MRI and brain mapping studies, testosterone has a beneficial effect on the microstructure of white matter. Moreover, positive associations have been reported between testosterone and white matter fractional anisotropy in boys ${ }^{(20,21)}$.

There is a conflict in the literature in terms gender-related differences in measurements. These discrepancies have been attributed to the differences in the age range of the sample group or in the number of male, and female subjects included in the studies ${ }^{(22-24)}$.

\section{Effect of Age and Sex}

In our study all parameters related to the size and length of CC showed increases with age in accordance with the literature, ${ }^{(5,17)}$. This study was performed on healthy children and subregions of CC showed proportional growth in healthy children. The present study has not demonstrated significant gender difference in age subgroups as for morphometry of the CC in children after 10 years old, which is consistent with the results of many studies cited in the literature. This finding suggests that CC acquires its adult form by about age $10^{(4,6,12,23)}$. However, we found some differences between the sexes in the 15-year-old group for supracallosal area and CC length which were larger in boys than girls. The correlation we found between these parameters is different from other studies, which may be due to ethnic, and hormonal factors, or the small number of patients included per age groups.

The size and degree of myelination of callosal fibers depends on their location. The large fibers are mostly placed in the isthmus which is responsible from connection between somatosensory, motor, auditory cortex. We also encountered large fibers in the posterior splenium (visual cortex). Thin fibers are localized in the genu and in the anterior splenium which connects prefrontal and temporoparietal lobes (4). We also investigated correlations of age and gender with the ratio of anterior to posterior fibers (GT/ST). The sex-related differences were seen in the 4-year age group for GT values and in the 5-year age group for GT/ST ratio, with higher values in girls compared with boys. In the 12 -year age group, GT/ST ratio was significantly higher in boys than in girls. In the literature, some studies have found significant relationships between the thickness of posterior body of the CC and academic success in language and mathematics. $\mathrm{Ng}$ et al. ${ }^{(12)}$ investigated the relationship between CC morphometry and gender, academic performance in Chinese children and concluded that language and mathematic skills are related to the shape and size of the fibers connecting both posterior parietal and temporal lobes.

When all age groups were evaluated separately, any significant gender differences were not found in ST and BT values. Allen et al. also found no gender difference in the area of CC or its subsegments in children from 2 to 16 years old. Nevertheless, they suggested that the shape of the splenium was more bulbous in girls than boys which makes it difficult to accurately measure and evaluate the corpus callosum $(12,23)$. 
Prendergast et al. ${ }^{(25)}$ observed different ageassociated changes through the lifetime of males and females in the subsegments of CC corresponding to the genu. Their findings implicate gender-related differences localized to the genu in CC morphology through the lifetime which apparently mediates neuropsychological functions.

Morphologic and size differences of CC can be seen in autism, dyslexia, attention deficit, hyperactivity disorders and other neuropsychiatric disorders. Hence morfologic and size determination of CC is important and beneficial in pediatric population with neuropsychiatric disorders. ${ }^{(5,25-27)}$. Therefore, it is important to identify the size and morphology of CC according to age and gender in childhood.

\section{Limitations}

Many factors implicated in CC growth and morphology have been reported. Various studies have indicated environmental factors, ethnicity, prematurity, mother's alcohol intake in prenatal period, and protein-poor diet that are effective in the development of CC $(10,28)$.

We did not question variables other than age, and gender which might be one of the limitations that affected the results of our study. Another limitation is that although we included a large number of participants in our survey, we evaluated each age group separately and the number of people per subgroup was relatively low. BMI values could not be obtained due to the retrospective design of the study. Lastly, images were assessed by a single radiologist. Therefore, interobserver agreement could not be evaluated. Handedness was not deliberately investigated because previous studies have shown that left-handed people's both hemispheres acting equal role in language, or that right-handed people have 1-5\% right hemisphere dominance ${ }^{(29)}$.

In conclusion; we provided reference normative data about the CC using multiple parameters on MR imaging in patients from 2 to 17 years of age and showed differences between age and gender. Modified callosal index did not display any gender- related changes. When we evaluated all age groups in combination, we determined that CCA and SCA are.

Ethics Committee Approval: This study was approved by the local ethics committee with the protocol file number: 2020/77.

Conflict of Interest: Authors have no conflicts of interest to declare.

Funding: None.

Informed Consent: Receipt.

\section{REFERENCES}

1. Raybaud C. Corpus Callosum Molecular Pathways in Mice and Human Dysgeneses. Neuroimag Clin N Am 2019;29: 445-59. https://doi.org/10.1016/j.nic.2019.03.006

2. Mihrshahi R. The Corpus Callosum as an Evolutionary Innovation. Journal of Experimental Zoology 2006;306B: 8-17. https://doi.org/10.1002/jez.b.21067

3. Tzourio-Mazoyer N. Intra- and Inter-hemispheric Connectivity Supporting Hemispheric Specialization. In: Kennedy H, Van Essen DC, Christen Y, editors. Micro-, Meso- and MacroConnectomics of the Brain. Springer; Cham (CH), 2016; pp. 129-46.

https://doi.org/10.1007/978-3-319-27777-6_9

4. Musiek FE. Neuroanatomy, neurophysiology, and central auditory assessment. Part III: Corpus callosum and efferent pathways. Ear Hear 1986;7(6):349-58. https://doi.org/10.1097/00003446-198612000-00001

5. Garel C, Cont I, Alberti C et al. Biometry of the Corpus Callosum in Children: MR Imaging Reference Data. American Journal of Neuroradiology 2011;32(8): 1436-43. https://doi.org/10.3174/ajnr.A2542

6. Hwang SJ, Ji EK, Lee EK et al. Gender differences in the corpus callosum of neonates. DevelopmentalNeuroscience Neuroreport 2004;15(6):1029-32. https://doi.org/10.1097/00001756-200404290-00019

7. Njiokiktjien C, Sonneville L, Vaal J. Callosal size in children with learning disabilities. Behav Brain Res 1994;64:213-8. https://doi.org/10.1016/0166-4328(94)90133-3

8. Woodruff PW, McManus IC, David AS. Meta-analysis of corpus callosum size in schizophrenia. J Neurol Neurosurg Psychiatry 1995;58:457-61. https://doi.org/10.1136/jnnp.58.4.457

9. Hynd GW, Hall J, Novey ES et al. Dyslexia and corpus callosum morphology. Arch Neurol 1995;52:32-8. https://doi.org/10.1001/archneur.1995.00540250036010

10. Kulak W, Sobaniec W, Kubas B, et al. Corpus Callosum Size in Children With Spastic Cerebral Palsy: Relationship to Clinical Outcome. Journal of Child Neurology 2007;22(4):371-4. https://doi.org/10.1177/0883073807300537

11. Rauch RA, Jinkins R. Analysis of cross-sectional area measurements of the corpus callosum adjusted for brain size in male and female subjects from childhood to adulthood. Behavioural Brain Research 1994;64:65-78. 
https://doi.org/10.1016/0166-4328(94)90119-8

12. Ng WHA, Chan Y, Au A et al. Morphometry of the corpus callosum in Chinese children: relationship with gender and academic performance. Pediatr Radiol 2005;35:565-71. https://doi.org/10.1007/s00247-004-1336-z

13. Luders E, Thompson PM, Toga AW. The development of the corpus callosum in the healthy human brain. Journal of Neuroscience 2010;30:10985-90. https://doi.org/10.1523/JNEUROSCI.5122-09.2010

14. Witelson SF. Hand and sex differences in the isthmus and genu of the human corpus callosum. A postmortem morphological study. Brain 1989;112:799-835. https://doi.org/10.1093/brain/112.3.799

15. Aboitiz F, Scheibel AB, Fisher RS et al. Individual differences in brain asymmetries and fiber composition in the human corpus callosum. Brain Research 1992;59:154-61. https://doi.org/10.1016/0006-8993(92)90179-D

16. Hasan KM, Kamali A, Kramer LA, et al. Diffusion tensor quantification of the human midsagittal corpus callosum subdivisions across the lifespan. Brain Research 2008;1227:5267. https://doi.org/10.1016/j.brainres.2008.06.030

17. Erdoğan $\mathrm{N}$, Ülger $\mathrm{H}$, Tuna $\mathrm{i}$, et al. A novel index to estimate the corpus callosum morphometry in adults: callosal/ supratentorialsupracallosal area ratio. Diagn Interv Radiol 2005;11:179-81.

18. Schaefer GB, Thompson JN, Bodensteiner JB et al. Quantitative Morphometric Analysis of Brain Growth Using Magnetic Resonance Imaging. J Child Neurol 1990;5(2):127-30. https://doi.org/10.1177/088307389000500211

19. Clarke S, Kraftsik R, Van der Loos $H$, et al. Forms and measures of adult and developing human corpus callosum: is there sexual dimorphism? J Comp Neurol 1989;280:21330. https://doi.org/10.1002/cne.902800205

20. Hahn A, Kranz GS, Sladky R, et al. Testosterone affects language areas of the adult human brain. Hum Brain Mapp2016;37(5):1738-48. https://doi.org/10.1002/hbm.23133
21. Rametti G, Carrillo B, Gomez-Gil E, et al. Effects of androgenization on the white matter microstructure of female-to-male transsexuals. A diffusion tensor imaging study. Psychoneuroendocrinology 2012;37:1261-69.

https://doi.org/10.1016/j.psyneuen.2011.12.019

22. Suganthy J, Raghuram L, Antonisamy B, et al. Gender- And Age-Related Differences in the Morphology of the Corpus Callosum. Clin Anat 2003;16(5):396-403. https://doi.org/10.1002/ca.10161

23. Sullivan EV, Rosenbloom MJ, Desmond JE, et al. Sex Differences in Corpus Callosum Size: Relationship to Age and Intracranial Size. Affiliations Neurobiology of Aging 2001;22(4):603-11. https://doi.org/10.1016/S0197-4580(01)00232-9

24. Prendergast $D$, Ardekani B, Ikuta $T$, et al. Age and Sex Effects on Corpus Callosum Morphology Across the Lifespan. Hum Brain Mapp. 2015;36(7): 2691-702. https://doi.org/10.1002/hbm.22800

25. Giedd JN, Castellanos FX, Casey BJ, et al. Quantitative morphology of the corpus callosum in attention deficit hyperactivity disorder. Am J Psychiatry 1994;151:665-69. https://doi.org/10.1176/ajp.151.5.665

26. Hill DE, Yeo RA, Campbell RA, et al. Magnetic resonance imaging correlates of attention-deficit/hyperactivity disorder in children. Neuropsychology 2003;17:496-506. https://doi.org/10.1037/0894-4105.17.3.496

27. Hardan AY, Pabalan M, Gupta N, et al. Corpus callosum volume in children with autism. Psychiatry Res 2009;174:5761. https://doi.org/10.1016/j.pscychresns.2009.03.005

28. Tepper R, Leibovitz Z, Garel C, et al. A New Method for Evaluating Short Fetal Corpus Callosum. Prenat Diagn 2019;39(13):1283-90. https://doi.org/10.1002/pd.5598

29. Bloom JS, Hynd GW. The role of the corpus callosum in interhemispheric transfer of information: excitation or inhibition? Neuropsychology 2005;15(2):59-71. https://doi.org/10.1007/s11065-005-6252-y 